\title{
上方伸展型の軟骨部外耳道瘻孔例
}

北林か执る1)・佐藤 宏昭 2$) ・$ 棚本 洋文 ${ }^{3)}$

村井 紀彦4) ・田㴊 圭作 ${ }^{1)}$

\section{A Congenital Fistula Extending into the Superior Cartilaginous Portion of the External Auditory Meatus}

\author{
Kaoru Kitabayashi and Keisaku Tabuchi \\ (Toyooka Hospital) \\ Hiroaki Sato \\ (Hyogo Prefectural Amagasaki Hospital) \\ Hirofumi Tanamoto \\ (Nishikobe Medical Center) \\ Norihiko Murai \\ (Kobe City General Hospital)
}

The case of a fistula in the cartilaginous portion of the external auditory meatus (EAM) is reported. A 14-year-old girl who had complained of left hearing impairment and discharge had admitted to our clinic.

The orifice of a fistula was found in the posterosuperior wall of the EAM. Computed tomography showed superior extension of this fistula into the cartilaginous portion of the EAM. The fistula was removed surgically and was believed to be an anomaly of the cartilaginous portion of the EAM.

This is the first report of a fistula that originated from the EAM and extended superiorly into the EAM.

Key words : fistula, external auditory meatus, superior extension

\section{はじめに}

外耳道に開口している瘻孔は比較的まれであるが第 1 鰓裂性（あるいは第 1 鰓溝性）の頸耳瘦として報告されて おり, それらは発生学的な理由から顎下部・下顎角部・ 側頸部等全て下方から㾇管が伸びている.一方，第 1 ・ 2 鰓弓性の先天性耳瘦孔は耳介の種々な部位に認められ るが外耳道に瘦孔開口部を持つ例は認められない。
今回我々は軟骨部外耳道後上壁に開口部を有しそこか ら上方に向かって伸びていた外耳道発育不全の為に発生 したと思われる瘦孔の 1 例を経験したので報告する.
症例：14歳，女性

主訴：左難聴.
1）公立豊岡病院耳鼻咽喉科

3）西神戸医療センター耳鼻咽喉科
2) 兵庫県立尼崎病院耳鼻咽喉科

4）神戸市立中央市民病院耳鼻咽喉科 
現病歴：幼少時より左外耳道が右に比べて狭い事に母 親は気付いていたが放置していた。1994年7月9日水泳 後主訴を自覚し，7月12日に当科を初診した。この時左 外耳道内に真珠腫 debris 様の耳垢を認め除去したとこ ろ聴力は正常に戻り放置していたが，50日後左耳漏が出 現し再診した。

既往歴・家族歴：特記事項なし.

局所所見：外耳道入口部は上方より圧排された形で狭 小化していた。入口部付近の debris 様の耳恬を除去し たところ入口部より $6 \mathrm{~mm}$ 内側の左軟骨部外耳道の後上 壁に瘦孔の開口部が認められた(図 1 ).

CT 所見：側頭骨 CT を施行したところ，冠状断にて 同部位に開口部を有する径 $6 \mathrm{~mm}$ の瘻孔を認めた。乳突 蜂巣内への侵入は無く，外耳道より上方の軟部組織内で 弧を描くように伸び盲端を形成していた(図 2).

治療：炎症を繰り返している事より外科的治療が必要 と考光，12月22日局所麻酔下に左外耳道瘻管摘出術を施 行した。耳後部に皮膚切開を加え瘦管に沿って剥離を進

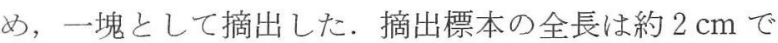
あった(図 3 )。外耳道皮膚欠損部は他家鼻中隔軟骨执よ び側頭筋膜にて裏打ちした。術後経過は良好で術後約 1 年 7 カ九経過した現在再発は認めていない。

病理組織学的所見: 瘦孔内腔は外耳道皮膚より連続し た角化重層扁平上皮で覆われていた（図４）。この上皮の

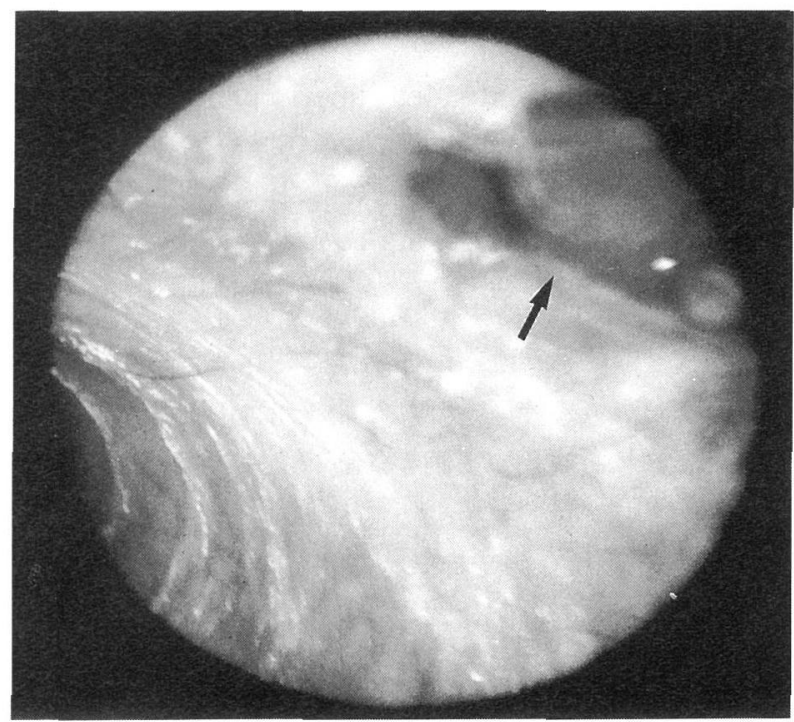

図 1 外耳道内視鏡所見 左軟骨部外耳道後上壁に瘦孔開口部を認める
基底層の表皮突起は過形成が著明であり，先天性瘦孔に 特徴的な組織所見を示した（図 5 )。あた管腔が蛇行した

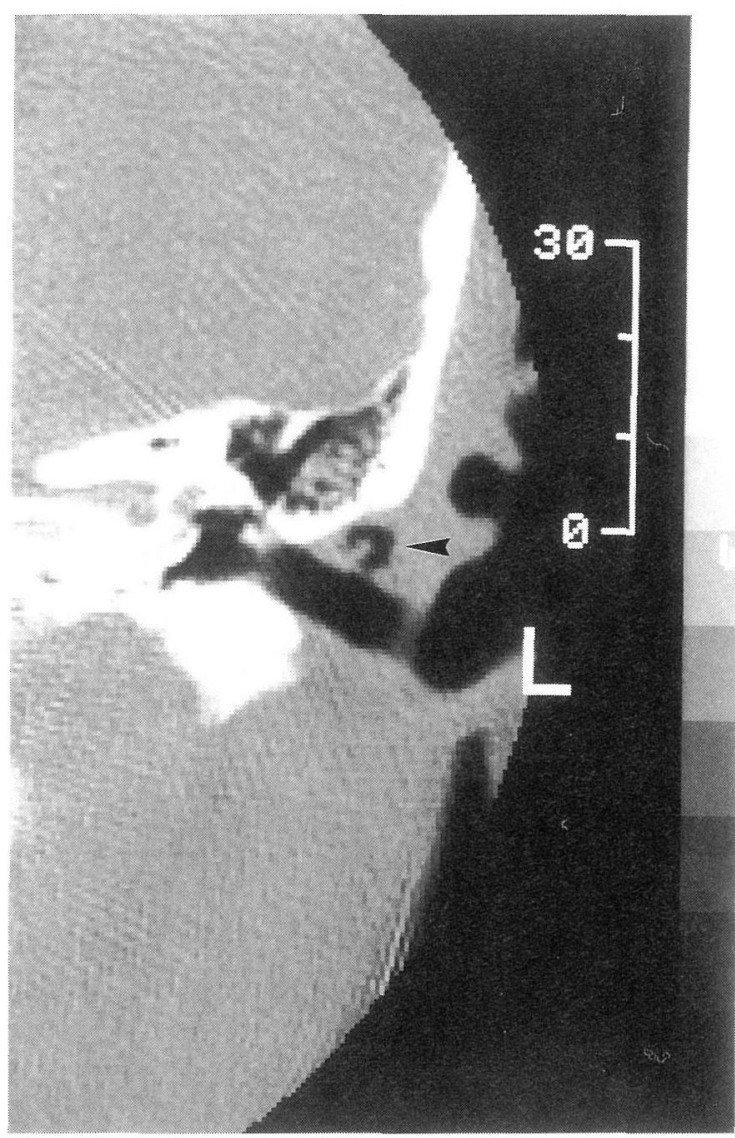

図 2 冠状断 CT 像 瘦孔の上方への伸展 $(<)$ を認める。
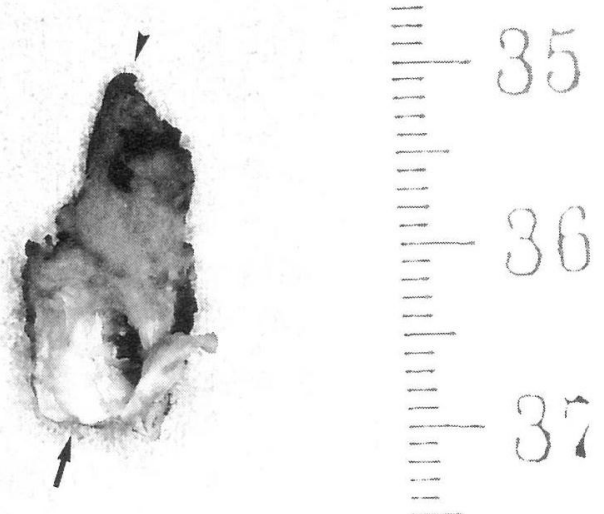

図 3 摘出した瘦管

開口部 $(\bullet)$, 盲端 $(つ)$ 。瘦管を引き伸ばして撮影 


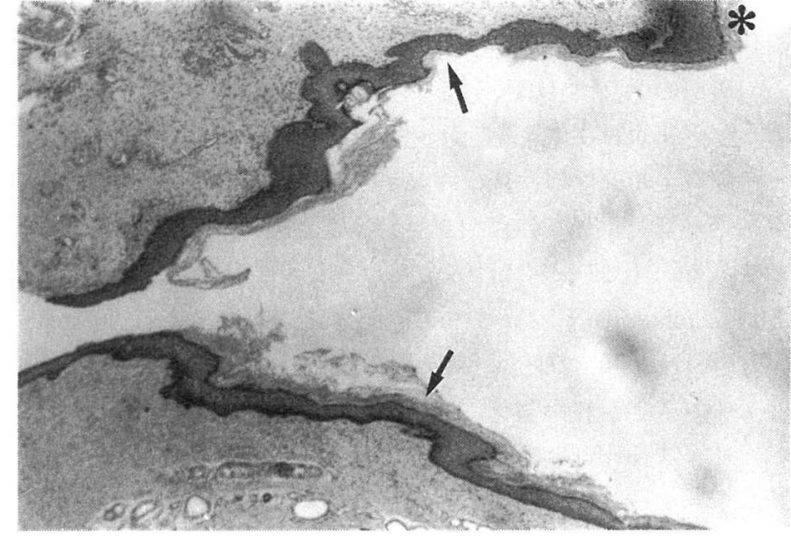

図 4 病理組織所見 (H-E 染色 40倍) 瘦孔内腔は外耳道皮膚から連続した角化重層扁平上皮で 覆われている。

瘻管壁 $(\bullet)$, 外耳道皮膚 $(*)$.

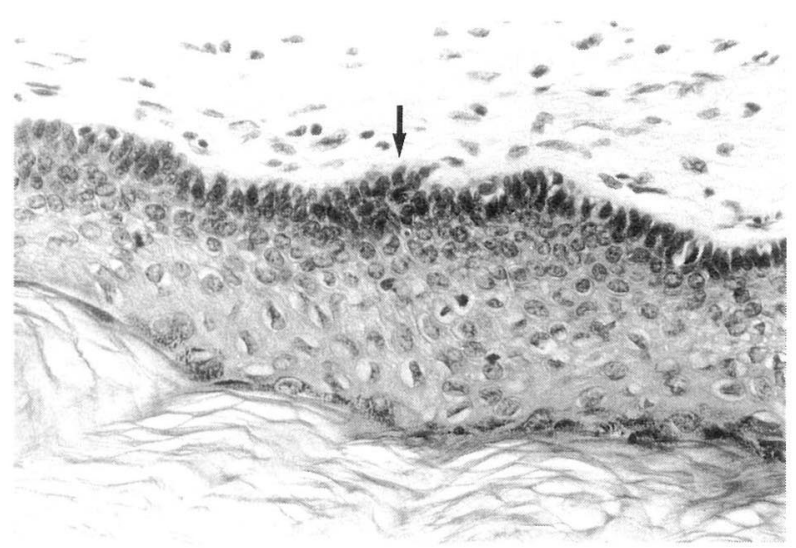

図 5 病理組織所見(H-E 染色 200倍) 瘦孔内腔の表皮突起は過形成が認められる(ヶ).

形態をとっている事, 外傷の既往が無い事, 解剖学的な 発生部位等から先天性瘻孔と診断された。

\section{考察}

本症例の鑑別診断として病理組織学的には(1)外耳道 真珠腫, (2) 皮様囊胞, (3) 類表皮囊胞, (4)表皮囊胞が 挙げられる。いずれも内腔が扁平上皮で覆われているが， (1) は骨部外耳道の骨膜や骨の炎症・骨破壊を伴い debris は粗で一定の配列をとらない1)，(2)(3)には外傷 の既往があり，(4)若年者では考光にくく(2) (3) (4)と も内腔上皮と皮膚上皮との連続は無い, とされている.
本症例は，外耳道皮膚より連続的に瘦孔が伸びている事， 病理組織学的所見の他に形態的にも蛇行した瘦管は真珠 腫とは考えにくい事, 外傷の既往が無い事等を根拠に先 天性瘻孔であると考学た。

鰓器はヒトの発生初期に将来顔の一部特よび頸部を形 成する為に出現する。即ち外胚葉面には 4 つの鰓溝とそ れをはさんで 5 つの隆起である鰓弓とがみられ，一方内 胚葉面には鰓溝に対応して 4 つの鰓囊が現れる。魚類で は鰓溝と鰓囊とは交通し鰓裂を形成するが，ヒトでは通 常両者の交通は生じず, 従って鰓裂は形成されない。し かし便宜上 1 組の鰓溝・鰓囊の単位を表す名称として 「鰓裂」という言葉を用いている2).

外耳の鰓原性奇形としては第 1 鰓弓・第 2 鰓弓・第 1 鰓溝・第 1 鰓裂の成長異常が関係する.日常診療でよく 見か子る先天性耳瘦孔は耳介周囲に好発し第 1 ・第 2 鰓 弓癒合不全によるものだがこれは盲端に終わり外耳道に 交通することは無い2). これに対して頸耳瘦は本来癒合 するはずのない第 1 鰓溝と第 1 鰓囊が癒合し第 1 鰓裂が 形成されるため生ずるが，従来より第 1 鰓裂性あるいは 第 1 鰓溝性の瘦孔とされて拉り, 英訳では裂溝いずれも “cleft”と称される。 Arnot ${ }^{3)} や W o r k{ }^{4)}$ はこのように混 同されていた瘻孔をtype I と type II に分類した。即 ら type I は, (1)外胚葉由来, (2)耳介下部から外耳道之 平行して深部に向かい中鼓室の近くで盲端に終わってい る瘻孔で外耳道とは交わらない, (3)膜性外耳道による重 複奇形であり，外肧葉性の扁平上皮で覆われ軟骨は認め ない，(4)皮膚付属器は伴らものと伴わないものとがある， といった特徴を持つ。一方 type II は, (1)外肧葉执よび 中胚葉由来, (2)下顎骨と舌骨との間の側頸部から上方に 走り顔面神経近傍を経て膜性外耳道の下に達するか外耳 道に開口する，(3)扁平上皮，皮膚付属器の他に軟骨が認

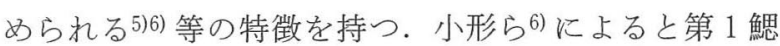
裂は第 1 鰓弓 (下顎骨, 咀嚼筋, 三叉神経, 耳介等の原 基) と第 2 鰓弓 (舌骨, 茎状突起, 顎二腹筋, 顔面神経, 上頸部皮膚等の原基)の間に存在するとされているため, 必然的に下方に伸びる。また相見7)によると第 1 鰓溝の 成人頸部に括ける位置は第 1 鰓弓に属する下顎骨の下方 で第 2 鰓弓性の舌骨より上方にあり, 従って外耳道入口 部之舌骨上縁を結ぶ線が第 1 鰓溝に相当すると考えられ る.

一方, Arnot ${ }^{3)}$ W Work ${ }^{4)}$ の分類を満たさない症例も あるとして Belenky ${ }^{8)}$ は解剖学的位置のみで type I • 
type II に分類した。彼によると type I とは耳介周囲 に囊腫や瘦孔として存在し, その瘦管は顔面神経の外側 もしくは上方を外耳道と平行するように伸び交わること なく盲端に終わる, type II は上頸部(通常下買角部)よ り襄腫・瘦孔・瘦管として始まり下顎角に沿って上に伸 び耳下腺と接したのち外耳道の骨部・軟骨部接合部に至 りそこで盲端に終わるか，もしくは外耳道に開口寸る.

さて本症例の特徵を挙げるとすれば次の 1 ) 〜 3)の事 が言える１）瘦管内腔は扁平上皮の久で形成されて拉 り中肧葉成分である軟骨は含んでいない，2)従来から 第 1 鰓溝が存在するとされている外耳道入口部から舌骨 上縁にかけての線上に開口部が存在しない． 3 )外耳道 後上壁に開口部がありそこから上方に瘦孔が伸びている.

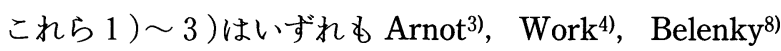
の言う type I・II の特徵を満たしてはいない。そして 掌握し得た範囲では外耳道と交通を持ちかつ外耳道より 上方へ伸びている鰓原性㾞孔の報告は無かった ${ }^{9) \sim 50) . ~}$ 以上の事柄扣よび外耳道入口部に狭小化を認めた事を考 えあわせると, 本瘦孔は耳瘦孔や頸耳㾇のような癒合不 全により発生したのでは無く, むしろ外耳道の発育異常 により発生したものと推定された。

\section{まとめ}

1. 軟骨部外耳道後上壁に開口し上方に向かい骨部外 耳道の拡大を伴う瘦孔の 1 例を報告した.

2. 㾇孔の形態, 部位扣よび組織学的検討により第 1 鰓溝由来と考えられた.

3. 本症例のような耳㾇孔・頸耳㾇の報告はこれまで に無く, 発生機序として鰓溝の癒合不全ではなく発育異 常によると推定された。

本論文の要旨は第 120 回日本耳鼻咽喉科学会兵庫県地方部会 (1995年 7 月 9 日, 神戸市)に拁いて口演した.

\section{参考文献}

1 ) 茂木五郎, 渡辺徳武 : 外耳道真珠腫. 耳鼻咽喉科・頭頸部 外科 MOOK No. 16 (中野雄一編). 219 226頁, 金原出版, 東京, 1990.

2 ) 本川広俊 : 鰓原性奇形. 現代外科学体系28巻(木本誠二監 修). 55 75頁, 中山書店, 東京, 1972 .

3 ) Arnot RS : Defects of the first branchial cleft. S Afr J Surg $9:$ 93 98, 1971.

4) Work WP : Newer concepts of first branchial cleft defects. Laryngoscope $82: 1581 \sim 1593,1972$.

5 ）横山道代，高山幹子，石井哲夫：耳下腺に及んだ第 1 鰓裂 囊胞の 1 例. JOHNS $11: 1759 \sim 1763,1995$.

6 ）小形哲也, 山本悦生, 大村正樹, 他：耳前部より副咽頭間 隙へ至る鰓性㾇孔例.耳鼻臨床 $87: 375 \sim 378,1994$.

7 ) 相見賢治 : 先天性側頸部瘦管及び霊腫に関する考察. 日耳 鼻 $69:$ 1919 1933, 1966.

8 ) Belenky WN : First branchial cleft anomalies. Laryngoscope $90: 28 \sim 39,1980$.

9 ）中木義浩, 村岡道徳, 原田輝一, 他 : 我々の経験した先天 性耳瘦孔139例について(会議録)。日耳鼻 $92: 2121,1989$.

10）村岡道徳, 中木義浩, 原田輝一, 他 : 先天性耳瘻孔につい て(会議録). 日形会誌 $9: 88,1989$.

11）伊東宗治, 中川 肇, 安田健二 : 耳㾞孔・頸瘻に感音性難 聴を伴った一家系(会議録)。日耳鼻 $90: 1270,1987$.

12）中川 肇, 渡辺行雄, 大橋值樹, 他 : 耳瘦孔, 頸耳瘦に難 聴を合併した Rowley 症候群と考えられる一家系(中耳所 見に関して) (会議録). 臨床耳科 $14: 168 \sim 169,1987$.

13）八木一記, 西端慎一, 八尾和雄, 他 : 先天性耳瘦孔の手術 例について. 耳喉頭頸 62:1175 1178, 1990.

14）大島猛史, 神林潤一：広範な膿瘍を形成した先天性耳瘦孔 2 例. 耳喉頭頸 $60: 399 \sim 402,1988$.

15）神林潤一, 若狭加奈子, 大島猛史 : 広範な膿瘍を形成した 耳瘦孔の治療法(会議録)。日赤医学 $40: 118,1988$.

16）西嶋信雄, 三枚三郎, 只木信尚 : 両側先天性耳瘦孔を伴っ た両側先天側頸瘦の 1 症例(会議録). 日耳鼻 $93: 1565$, 1990.

17）羽成敬一, 関 守広 : 先天性耳瘻孔の15手術症例(会議録)。 日耳鼻 $93: 1411,1990$.

18）藤木宏也, 木村純平 : 先天性耳瘦孔の手術療法(会議録). 日耳鼻 $90: 1447,1987$.

19）佐久間仁, 村上正文, 宗田由美, 他 : 頸耳瘦孔の 1 症例 (会 議録). 日耳鼻 $92: 271,1989$.

20）佐藤春生, 藤吉達也, 渡辺徳武, 他 : 広範な耳前部膿瘍を きたした先天性耳瘦孔の一例(会議録)。臨床耳科 $14: 490$ $\sim 491,1987$.

21）河合敬一, 若林俊治 : 耳瘦孔の 1 例 (会議録). 皮膚科紀要 $82: 513,1987$.

22）乗金陽子, 金川清人，山内了平，他：耳介軟骨炎を併発し た先天性耳瘦孔及び第 1 鰓溝性側頸瘻の 2 例 (会議録)。日 耳鼻 $91: 1960,1988$.

23）桶口明文, 宾戸 潔 : 当教室で手術を行った先天性耳瘻孔 症例(会議録)。日耳鼻 $93: 1128,1990$.

24）森 理, 井ノ口憲一郎：感染粉瘤様外観を呈した先天性 耳瘦孔の 1 例. 臨皮 $46: 737 \sim 738,1992$.

25）飯田政弘, 荻野化志, 小川 裕, 他：先天性耳㾇孔の統計 的検討. 臨床耳科 $14: 116 \sim 117,1987$.

26）宮永 守, 新川 敦, 飯田政弘, 他 : 加療を必要とした先 
天性耳瘦孔. 臨床耳科 $14: 118,1987$.

27）池田元久, 渡辺 勈：耳瘦孔を伴う右側頸襄胞・左側頸瘦 孔例. 耳鼻臨床 85 : 1955 1959, 1992 .

28）岩崎 聡，加納有市，星野知之，他：親子に見られた Branchio-Oto-Renal 症候群. 耳鼻臨床 88 : 183 188, 1995.

29）麻生和雄, 梅津明美 : 難聴を伴った両側耳瘦孔一Earpiut-deafness 症候群とおるわれる症例一, 皮膚臨床 28 : $355 \sim 357,1986$.

30）石倉直敬, 加田顕秀 : 皮膚開口部を認めない先天性耳瘦孔 の一例. 皮膚臨床 $32: 1916 \sim 1917,1990$.

31）縄田安孝，市川銀一郎，上原紀夫，他：第 1，第 2 鰓弓複 合奇形. 耳鼻臨床 $83: 377 \sim 381,1991$.

32）柏 英雄, 中村雄幸, 惣角卓矢 : 両側耳前瘦孔を伴った先 天性外沪裹瘦の 1 例. 形成外科 $37: 685 \sim 689,1994$.

33）黒川正人，小山久夫：巨大な襄胞を形成した先天性耳瘦孔 の 1 例. 皮膚科紀要 $85: 189 \sim 192,1990$.

34）増田 游, 深沢元晴, 西岡絵里子, 他 : 骨性鼓膜と外耳道 真珠腫・耳瘦孔・副耳を有した先天性外耳道閉鎖症の 1 例. 臨床耳科 $14: 324 \sim 325,1987$.

35) Ford GR : Branchial cleft and pouch anomalies. J Laryngol Otol $106: 137 \sim 143,1992$.

36) Takimoto $T$ : Branchial cleft (pouch) anomalies ; a review of 42 cases. Auris Nasus Larynx (Tokyo) $18: 87 \sim 92,1991$.

37) Baader WN : First branchial cleft cysts presenting as parotid tumors. Ann Plast Surg 33 : 72 74, 1994.

38) de Gaudemar I : Unusual presentation of a first branchial cleft. Eur Arch Otolaryngol 252 : 57 60, 1995.

39）柊山幹子, 牧野浩二, 井手 稔, 他 : 第一鰓溝瘦孔および 襄腫の 6 例. 耳鼻 $36: 264 \sim 270,1990$.

40）中野友明, 村岡道徳, 兵頭哲裕, 他 : 頸耳瘦の 1 症例. 形
成外科 $35: 1523 \sim 1528,1992$.

41）宇野芳史, 斉藤龍介, 松岡寿子, 他 : 耳下腺内に発生した 鰓性囊胞例. 耳鼻臨床 $85: 601 \sim 605,1992$.

42) Tom LW : First branchial cleft anomalies involving the tympanic membrane and middle ear. Otolaryngol Head Neck Surg $105:$ 473 477, 1991.

43) Todd NW : Common congenital anomalies of the neck. Surg Anat Embryol 73 : 599 610, 1993.

44) Berenholz LP : Type I first branchial (pharyngeal) cleft cyst presenting as a lop ear deformity. Otolaryngol Head Neck Surg $113:$ 151 152, 1995.

45) Mounsey RA : First branchial cleft sinuses ; an analysis of current management strategies and treatment outcomes. J Otolaryngol 22 : 457 461, 1993.

46) Murthy $P$ : First cleft branchial fistula in a child; a modified surgical technique. J Laryngol Otol 108 : 1078 1080, 1994.

47) Hickey SA : Defects of the first branchial cleft. J Laryngol Otol $108: 240 \sim 243,1994$.

48) Gonzalez LM : First branchial cleft anomaly; a case report. J Oral Maxillofac Surg 49 : 200 204, 1991.

49) Olsen KD : First branchial cleft anomalies. Laryngoscope $90: 423 \sim 436,1980$.

50）庄野佳孝, 中西秀樹, 長江浩朗, 他 : 第 1 鰓裂由来の瘦孔 および囊腫の 3 例. 形成外科 $37: 1291 \sim 1297,1994$.

原稿受付: 平成 8 年11月19日 原稿採択: 平成 9 年 1 月 22 日 別刷請求先 : 北林か未る Ү668 豊岡市立野町6-35 公立豊岡病院耳鼻咽喉科 